\title{
The Elements of Teaching
}


This page intentionally left blank 


\section{The Elements of Teaching}

Second Edition

$$
\text { ๙ }
$$

James M. Banner, Jr., and Harold C. Cannon

Foreword by Andrew Delbanco 
Published with assistance from the foundation established in memory of Philip Hamilton McMillan of the Class of 1894 , Yale College.

Copyright (C) 1997, 2017 by Yale University. All rights reserved. First edition 1997. Second edition 2017. This book may not be reproduced, in whole or in part, including illustrations, in any form (beyond that copying permitted by Sections 107 and 108 of the U.S. Copyright Law and except by reviewers for the public press), without written permission from the publishers.

Yale University Press books may be purchased in quantity for educational, business, or promotional use. For information, please e-mail sales.press@yale.edu (U.S.office)or sales@yaleup.co.uk (U.K.office).

Designed by Sonia L. Shannon.

Set in Fournier type by Newgen North America. Printed in the United States of America.

Library of Congress Control Number: 2016941944 ISBN 978-0-300-2 I 855-8 (paper : alk. paper)

A catalogue record for this book is available from the British Library.

This paper meets the requirements of ANSI/NISO Z39.48-1992 (Permanence of Paper).

I0 $9 \begin{array}{lllllllll} & 8 & 7 & 6 & 5 & 4 & 3 & 2 & \text { I }\end{array}$ 